\title{
Influence of «adding blood» of cocks of foreign crosses upon economically beneficial attributes of meat-egg hens of domestic selection
}

\author{
V. Khvostyk, \\ doctor of agricultural sciences \\ O. Tereshchenko, \\ candidate of biological sciences \\ O. Zakharchenko, \\ researcher State Poultry Research Station NAAS \\ Yu. Bondarenko, \\ doctor of biological sciences, Sumy NAU
}

The purpose. To enrich economically beneficial attributes of meat-egg hens of domestic gene pool at crossing with genetic material of foreign selection. Methods. Selection-and-genetic, zootechnical, biometric, systemic approach, theoretical analysis and synthesis. Results. As a result of introduction of new genetic material of auk of foreign highly productive meat crosses «Kobb-500» and «Ross-308» into gene pool of meat-egg hens of local population their adaptive and productive attributes were improved, the level of variability that created good preconditions for increase of genetic potential and combinational variability of auk of domestic selection was raised. Conclusions. Expediency and perspective of use in the breeding purposes is proved of cocks of final hybrid of foreign meat cross «Ross-308» at their prolong use for improving indices of alive mass and egg production of meat-egg hens of domestic gene pool.

Key words: meat-egg hens, economically beneficial attributes, cocks of import meat crosses, crossing.

Relevance of research. Meat-egg poultry domestic selection for a long time bred "in itself" by the methods of mass selection, as a result of which its useful features deteriorated somewhat and therefore immediately needed improvement. Therefore, there was an urgent need to improve the main productive features of meat-egg hens for crossing high-yield crosses of foreign selection with the poultry.

Since the breeding of meat-egg hens at different stages of breeding used Cobb-500 and Ross-308 crossover producers, the task was to evaluate the effectiveness of their heredity influence on the expression of economically useful qualities of meat-egg poultry. About the use of the final hybrid in breeding work (the direct purpose of which is fattening for meat at a young age) to improve the productive characteristics of meat-egg hens, so it was decided to practically study this from the question.

Analysis of recent research and publications. In various branches of domestic livestock production, foreign selection material has recently been widely used for carrying out various types of crossing, which are used both in the creation of new breeding achievements and in the improvement of certain economic useful traits in existing breeds of animals of various species $[3,4,6,8,9]$.

In poultry farming, as well as for improving productive indicators, domestic selection birds widely use crosses with highly productive import crosses $[1,2,5,7,11,13,14]$.

In the absence of breeding plants in Ukraine, individual selection with meat-egg chickens, the lack of own genetic resources for chicken meat crosses, to determine the potential for effective use in breeding and breeding of meat cocks of final hybrids, repeatedly attracting them to the breeding process to improve the economically useful traits meat-egg hens of the domestic gene pool, a reduction in the cost of purchasing breeding material of ancestral or parental forms the search for non-traditional ways to improve meat-and-egg poultry for household and farming enterprises becomes urgent. In this regard, the task was set in practical terms to study the effectiveness of the introductory crossing of males of the final cross-breed hybrid Ross308 with meat-egg chickens of domestic selection. In addition, in Ukraine the poultry of parental flocks and broilers of meat chicken from the leading import crosses "Cobb-500" and "Ross-308" has been widely disseminated [10,12], and therefore it becomes relevant to involve it in the selection process for assessment 
Influence of heredity on the expression of productive qualities of domestic meat-egg poultry, while maintaining its characteristic of high adaptive capacity.

The purpose of the research is to improve the economically useful signs of meat-egg hens of the domestic gene pool while crossing with the genetic material of foreign selection.

Materials and methods of research. Roosters of meat crosses "Cobb-500" and "Ross-308" with meategg chickens (F9) of Plymutrok white breed, breeding work with which is conducted in the breeding plant of the State Research Station of poultry farming of the National Academy of Sciences of Ukraine. As a result of crosses, the descendants of the first generation (F1) of the "K-1" and "K-2" groups were obtained. In the case of the reverse crossing of the mating cocks of the "Cobb-500" and "Ross-308" crosses with the young hybrid chickens of the F1 groups "K-1" and "K-2", the second generation (F2) hybrids of the "K-51" and the "K-32". In addition, hybrids F1 groups "K-1" and "K-2" were bred "in themselves", resulting in their descendants of F2 groups "K-11" and "K-22". By combining the chickens of the original parental form, the descendants of $\mathrm{F} 2$ of different groups created a synthetic population of meat-egg hens, conditionally designated as the "K-5" group.

The object of the research was the meat-egg chickens of the original maternal form F9-F11, the descendants of the F1 groups "K-1" and "K-2", the chickens of the F2 groups "K-11", "K-22", "K-51", "K-32" and synthetic population "K-5".

Methods of research - selection-genetic: selection and selection of desired genotypes, phenotypic assessment of a hybrid bird; zootechnical: definition of productive and reproductive qualities of a bird; biometric: correlation, dispersion analysis; systems approach; theoretical analysis and synthesis.

Results of the research. At the first stage of the work on artificial insemination of meat-egg hens with the polysperm of the cocks of the parent form of the cross "Cobb-500", the fertilization of eggs was $78.2 \%$, hatchability of eggs $-85.8 \%$, the yield of young animals was $67.1 \%$. When breeding meat and eggs of the local population "K" (F9) "in itself", reproductive qualities were somewhat higher: egg fertilization at the level of $80.3 \%$, hatchability of eggs $-91.2 \%$, the yield of the young was $73.2 \%$. A somewhat smaller value of the reproductive qualities was obtained in the group of hens inseminated with the polysperm of the roosters of the final "Ross-308" hybrid: the fertilization of eggs was $71.0 \%$, the hatchability of eggs was $87.9 \%$ (by the way, $2.1 \%$ more than in the group females, which were inseminated with the sperm of the cocks of the cross "Cobb-500"), the yield of the young - $62.5 \%$.

The obtained results showed the real possibility of obtaining sperm products of sufficiently good quality from broiler cocks at the age of 12 months, the direct purpose of which is fattening for obtaining meat at a very young age (6-7 weeks of life) and obtaining from them viable offspring.

Crosses of meat-egg hens with rooster parents of the cross-type "Cobb-500" significantly increased the live weight of hybrid descendants of the first generation at all stages of early ontogeny (by 6.84-33.48\%), probably increased the mass of eggs at 52-week-old chickens by $1.8 \mathrm{~g}$, but reduced egg production by 18.8 eggs compared to the baseline population.

Hybridization of meat-egg hens with roosters "Ross-308" increased only the growth energy of the young F1 before the 10-week age (by 3.14-14.54\%), but did not affect the economically useful signs of adult birds that were on level of the original maternal form.

At the next stage of the work, based on the results of the conducted experimental studies, it can be concluded that the breeding of "cob" F1 hybrids "in oneself" and the reverse crossing of hybrid F1 females with mating cocks "Cobb-500" contributed to an increase in the F2 offspring in the early ontogenesis (2-17 weeks) by $3.35-15.28 \%$, in the adult age (52 weeks) - by $8.23-23.33 \%$, the mass of eggs in the young (by $1.06-1.23 \mathrm{~g}$ or $2,34-2.72 \%$ ) and the adult (in $1.55-1.93 \mathrm{~g}$ or $2.48-3.09 \%$ ), but at the same time reduced the egg production by $7.7-10.1$ eggs (or 8.19-11,03\%) compared with the original maternal form (table 1 ). 
Table 1. Economically useful signs of the hens of experienced groups

\begin{tabular}{|c|c|c|c|c|c|c|c|c|c|}
\hline \multirow{3}{*}{$\begin{array}{l}\text { Chicken } \\
\text { group }\end{array}$} & \multicolumn{4}{|c|}{ Live weight, $\mathrm{kg}$} & \multicolumn{2}{|c|}{$\begin{array}{l}\text { The mass of eggs, } \\
\mathrm{g}\end{array}$} & \multirow{3}{*}{$\begin{array}{l}\text { Egg } \\
\text { production for } \\
30 \quad \text { weeks, } \\
\text { eggs }\end{array}$} & \multirow{3}{*}{$\begin{array}{l}\text { Fertility } \\
\text { eggs, \% }\end{array}$} & \multirow{3}{*}{$\begin{array}{l}\text { Withdra } \\
\text { wal of } \\
\text { the } \\
\text { young, } \\
\%\end{array}$} \\
\hline & \multicolumn{2}{|c|}{17 Weeks } & \multicolumn{2}{|c|}{52 Weeks } & \multirow{2}{*}{$\begin{array}{l}24 \\
\text { Weeks }\end{array}$} & \multirow{2}{*}{$\begin{array}{l}52 \\
\text { Weeks }\end{array}$} & & & \\
\hline & $\hat{0}$ & q & $0^{\pi}$ & 우 & & & & & \\
\hline „K”, F11 & 2,88 & 2,14 & 4,03 & 3,16 & 45,3 & 62,6 & 101,7 & 91,8 & 82,9 \\
\hline „K-11” & 3,12 & 2,27 & 4,50 & 3,42 & 46,5 & 64,5 & 91,6 & 83,7 & 79,1 \\
\hline „K-22” & 3,03 & 2,30 & 4,32 & 3,33 & 46,7 & 61,9 & 109,1 & 77,3 & 72,0 \\
\hline „K-51” & 3,32 & 2,29 & 4,97 & 3,66 & 46,3 & 64,1 & 94,0 & 89,0 & 80,5 \\
\hline „K-32” & 3,20 & 2,33 & 4,74 & 3,50 & 46,6 & 61,6 & 107,9 & 75,9 & 65,5 \\
\hline
\end{tabular}

Whereas, the breeding of the "rosovian" bird F1"in itself" and the reverse crossing of hybrid females F1 with the mating roosters of the "Ross-308" improved the live weight of offspring at the 12-week-old age by $7.37-11.89 \%$, in the 17 -week - by $5.21-11.11 \%$, did not significantly affect the weight of eggs in the descendants of F2 (it was at the level of the original maternal form), but contributed to an increase in egg production by 6.2-7.4 eggs or 6.10- 7.28\% compared with the meat-egg hens of the basic population.

Fertility of eggs was higher in meat-egg chickens of domestic selection and significantly more in comparison with the "ross" bird. In the "kobb" hens of the "K-11" and "K-51" groups, the egg fertilization was also higher by $6.4-13.1 \%(P>0.95)$ than in the "ross" ones. The largest output of chicks was observed in meat-egg hens of the original form - $82.9 \%$, which is $2.4-3.3 \%$ more than in "kobb" hybrids and $10.9-17.4 \%$ $(\mathrm{P}>0,99)$ in comparison with the "ross" ones. In the "kobb" chickens of the groups "K-11" and "K-51" the output of chickens is more by $7.1-15.0 \%$ ( $P>0.95)$ than that of the "ross" ones.

From the experimental data obtained, it can be seen that some important adaptive features (egg fertilization, young growth, preservation of young animals and adult livestock), birds of two new microlines (conditionally called "kobivskoi" and "rosisskoyu") were slightly lower than in the original population. Therefore, it was decided to expand and enrich its gene pool due to introgression of genes from poultry created by microlines.

For this purpose, a group of individuals was formed from different microlines, which accidentally mated with each other. In this case, among the total number of this group, the number of males and females of the original form was $50 \%$, and the created microlines ("kobovskaya" and "rosovskaya") - $25 \%$ each. Theoretically, it was assumed that the bird of the original population would be well adapted to local conditions and introduce a good group of meat-egg hens into the new group, first of all, good adaptive and reproductive qualities, while roosters and chickens of the " kobovskaya " microline will be the source of genes for high growth energy and egg mass, and "rosovskaya" introduces hereditary factors (alleles) of high egg production into a new synthetic heterogeneous population.

Conducted observations of the adaptive and productive features of a newly heterogeneous subpopulation, codenamed code-named "K-5", on the whole confirmed these theoretical arguments. The overwhelming majority of the productive signs of meat-egg hens of the created synthetic population "K-5" have improved in comparison with the previous generations (F9-F11) of the birds of the initial base population (table 2).

Table 2. The economically useful signs of meat-egg hens in the dynamics of generations

\begin{tabular}{|c|c|c|c|c|}
\hline \multirow[t]{2}{*}{ Productive features } & \multicolumn{4}{|c|}{$\begin{array}{l}\text { Generation from the beginning of the } \\
\text { research }\end{array}$} \\
\hline & F9 & F10 & F11 & F12 \\
\hline Live weight in 17 weeks, kg: roosters & 2,95 & 3,09 & $2,88 a$ & 3,196 \\
\hline chicken & 2,27 & 2,34 & $2,14 \mathrm{~B}$ & $2,32 \Gamma$ \\
\hline Live weight in 52 weeks, kg: roosters & 3,81 & 4,41 & $4,03 a$ & 4,546 \\
\hline chicken & 2,89 д & 3,39 & $3,16 \mathrm{~B}$ & 3,54ге \\
\hline Weight of eggs, g: at 24 weeks & 52,05 & 52,67 & 45,27д & $53,18 \mathrm{e}$ \\
\hline
\end{tabular}




\begin{tabular}{|l|l|l|l|l|}
\hline \multicolumn{1}{|c|}{ 30 weeks } & 53,60д & $56,39 а$ & $54,31 д$ & $57,59 б е$ \\
\hline 52 weeks & $59,91 д$ & 62,70 & 62,55 & 63,45 е \\
\hline Egg production for 30 weeks of lay eggs: & & & & \\
\hline to the initial layer & 89,1 & 101,0 & 101,7 & 116,3 \\
\hline on the middle layer & 90,4 & 101,8 & 102,3 & 116,6 \\
\hline Preservation of young animals up to 17 weeks,\% & 90,7 & 90,6 & 92,9 & 97,9 \\
\hline Preservation of adult livestock, \% & 90,4 & 91,3 & 92,5 & 98,0 \\
\hline Fertility eggs, \% & 80,3 & 86,4 & 91,8 & 84,3 \\
\hline Hatchability eggs, \% & 91,2 & 95,2 & 90,3 & 90,8 \\
\hline Withdrawal of young animals, \% & 73,2 & 82,3 & 82,9 & 76,5 \\
\hline
\end{tabular}

Note: a:б - P>0,95; в:г - P>0,99; д:e - P>0,999.

Thus, in comparison with previous generations, the live weight of poultry in young (100-310 grams of cocks, $50-180 \mathrm{~g}$ of chickens) and adult age (cocks for 130-730 g, chickens for 150-650 g), egg mass in different age periods, the egg-laying (for the initial layer of hen on 14.5-27.2 eggs, for the average layer - for 14.3-26.2 eggs), the viability of the young (by 5.0-7.3\%) and adult livestock (by 5.5-7.6\%). The reproductive qualities of the chickens of the heterogeneous population created were good. Fertility of eggs was $84.3 \%$, hatchability of eggs $-90.8 \%$, output of young animals at the level of $76.5 \%$, which was higher or at the level of the period of research.

Crossbreeding of meat-egg hens of domestic selection with roosters of meat crosses of foreign origin made it possible to obtain additional basic products in the amount of $48.02 \mathrm{UAH}$ on 1 head as a result of the increase in the egg-laying capacity of the bird and 6,75-7,09 UAH on 1 head in the implementation of adult chickens for meat due to an increase in their live weight in adulthood compared with the original form.

\section{Conclusions.}

Crossbred cocks imported high-performance meat crosses "Cobb-500" and "Ross-308" with meat-egg chickens of domestic selection contributed to improving their adaptive and productive characteristics, increasing the level of variability, creates good prerequisites for increasing the genetic potential and combinational variability of birds in the local population.

\section{Bibliografija}

1. Danylenko V. P. Naukovo-praktychne obg'runtuvannja metodiv formuvannja vysokoproduktyvnogo stada molochnoi' hudoby : avtoref. dys. na zdobuttja nauk. stupenja kand. s.-g. nauk : spec. 06.02.01 „Rozvedennja ta selekcija tvaryn” / V. P. Danylenko. - s. Chubyns'ke Kyi'vs'koi' oblasti, 2007. - 20 s.

2. Kalynka A. K. Formuvannja stad m'jasnogo komologo symentala / A. K. Kalynka, L. V. Shpak, Ju. V. Vdovychenko // Visnyk agrarnoi' nauky. - 2011. - №8. - S. 34 - 38.

3. Lisnyj V. A. Efektyvnist' vykorystannja perspektyvnogo genofondu svynej u systemi gibrydyzacii' / V. A. Lisnyj, T. M. Lisna, V. I. Novyc'kyj // Tavrijs'kyj naukovyj visnyk. - Herson, 2011. - Vyp. 76, ch. 2. - S. $15-18$.

4. M'jasni porody ovec' u Prydniprov'i' / V. Pohyl, O. Pohyl, A. Gonchar [ta in.] // Tvarynnyctvo Ukrai'ny. 2011. - №9. - S. 17 - 20.

5. Polupan Ju. P. Genetychna determinacija efektyvnosti dovichnogo vykorystannja chorno-rjaboi' molochnoi' hudoby / Ju. P. Polupan // Rozvedennja i genetyka tvaryn: Mizhvid. temat. nauk. zb. - K., 2003. - Vyp. 35. - S. $108-117$.

6. Autoseksnyj jaichnyj kross kur „Ptichnoe-2” / Ju. Kosincev, M. Annenkova, V. Annenkov [i dr.] // Pticevodstvo. - 2005. - №7. - S. 2 - 3.

7. Bogatyr V. P. Vplyv vvidnogo shreshhuvannja na vidtvorni jakosti materyn-s'koi' linii' kolorseksnogo krosu / V. P. Bogatyr // Ptahivnyctvo: Mizhvid. temat. nauk. zb. (Mat. V Ukr. konf. po ptah-vu z mizhnarod. uch., 20-24 sentjabrja, 2004 g., g. Alushta, AR Krыm) / IP UAAN. - Har'kov, 2004. - Vyp. 55. - S. 32 - 37.

8. Kletochnaja tehnologija soderzhanija mjasnyh krossov/l. Gal'pern, V. Sinichkin, V. Slepuhin [i dr.] // Pticevodstvo. - 2009. - №6. - S. 22 - 23. 
9. Mal'cev A. B. Priemy selekcii pri sozdanii linii porody kornish / A. B. Mal'cev, A. B. Dymkov // Mat. X Ukr. konf. po pticev-vu s mezhdunarod. uch. „Aktual'nye problemy sovremennogo pticevodstva” (15-18 sentjabrja, 2009 g., g. Alushta). - Har'kov, 2009. - S. 236 - 240.

10. Rojter Ja. Rol' genofonda v sozdanii novyh porod i krossov / Ja. Rojter // Zhivotnovodstvo Rossii. 2010. - №1. - S. 19 - 20.

11. Stresostijki linii' indykiv vitchyznjanoi' selekcii' / O.T.Gadjuchko, Ju.O.Rjabokon', O. O. Katerynych [ta in.] / Ptahivnyctvo: Mizhvid. temat. nauk. zb. (Mat. VII Ukr. konf. po ptah-vu z mizhnarod. uch., 18-22 veresnja, 2006 g., m. Alushta, AR Krym) / IP UAAN. - Harkiv, 2006. - Vyp. 58. - S. 49 - 62.

12. Tuchemskij L. I. Priemy selekcii linij autoseksnogo krossa mjasnyh kur „Smena7” / L. I. Tuchemskij, G. V. Gladkova, Zh. V. Emanujlova // Mat. XVI konf. VNAP „Dostizhenija v sovremennom pticevodstve: issledovanija i innovacii". - Sergiev Posad, 2009. - S. 64 - 66.

13. Prybuz'kyj M. Krosy m'jasnoi' ptyci / M. Prybuz'kyj // Nashe ptahivnyctvo. - 2012. - №1. - S. 26 - 27.

14. Stepanenko I. A. Harakterystyka genetychnyh resursiv ptyci u ptahogospodarstvah Ukrai'ny I I. A. Stepanenko // Suchasne ptahivnyctvo. - 2009. - №8(81). - S. 5 - 9. 